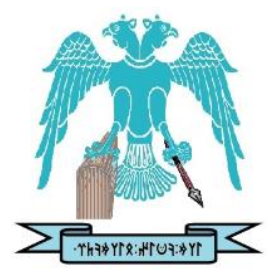

JOURNAL OF ENERGY SYSTEMS

2022, 6(1)

\title{
An evaluation of the glazing type impact on building energy performance through a building simulation
}

\author{
Pinar Usta (1) \\ Isparta University of Applied Science, Isparta , Türkiye, pinarusta@isparta.edu.tr
}

Başak Zengin (D)

Nişantaşı University, İstanbul, Türkiye, zenginbasak@gmail.com

\begin{abstract}
Buildings are responsible for most of the energy consumption in countries, thence energy saving in buildings is a high priority issue. Windows and glazing types are one of the factors that greatly affect the performance of buildings, both in terms of thermal comfort and energy consumption for heating or cooling. The proper selection of window glazing is one of the effective strategies to minimize energy consumption. In this study, an office building was designed to determine the most suitable glazing type for office buildings, which is the main purpose, and the energy efficiency of the building was examined with Openstudio and Energyplus software. Energy modeling of the office building was conducted for four different types of glazing by using VRF systems for airconditioning and a dedicated outdoor air system for ventilation. The effect of different windows glazing system properties on the energy performance and total energy need was calculated by considering the fixed indoor thermal and visual comfort conditions were evaluated. The study results indicated that energy consumption can reduce about $24.88 \mathrm{kBtu} / \mathrm{ft} 2(25 \%)$ using suitable glazing material.
\end{abstract}

Keywords: Energy, Energy demand, Energy efficiency, Energy saving, Window glazing

Cite this paper Usta, P., \& Zengin, B., An evaluation of the glazing type impact on building energy as: performance through a building simulation. Journal of Energy Systems 2022; 6(1): 1-17, DOI: $10.30521 /$ jes.945193 


\section{INTRODUCTION}

Nowadays, climate change is a huge and long-term challenge facing the world [1]. Energy and thermal performance in buildings have gained global importance in recent years due to the goal of maintaining thermal comfort with a more efficient approach. With the increasing importance of energy efficiency, the analysis of the capacities of buildings for energy saving has become mandatory in the construction industry. An adequate energy performance analysis is necessary for heating, ventilation, air conditioning (HVAC) systems, building materials, architectural design, etc. [2].

The energy efficiency of the built environment in urban areas plays an important role in reducing the problems of climate change, resource depletion, and environmental challenges at large. Due to higher contemporary living standards and rapid urbanization, energy-consuming appliances such as air conditioners and urban building areas will increase people's energy consumption. Accordingly, the energy consumption levels of buildings will increase soon [3].

For commercial buildings, energy is mainly consumed in lighting, while for residential buildings the consumption is mainly for heating and cooling [4].

The glazed building facade imposed itself as an icon for developing cities. The inclusion of a large area of glazing in facades requires in-depth studies to avoid high energy consumption for cooling and heating during the year [5].

Many researchers have discovered that there is tremendous energy-saving potential in the outer shell of the building, especially in its exterior windows. Most of the unwanted heat gains come from the window through sunlight radiation and air infiltration. Windows are the most vulnerable area of the building in terms of heat gain. Therefore, it always plays an important role in reducing energy consumption for a room space Wang [3]. In recent years, glass facades have been widely used in buildings. The presence of these glass components has often been the subject of analysis due to the effect of solar energy on the thermal energy performance of the building in both summer and winter seasons, lighting energy demand, thermal and visual comfort [6].

One of the most common causes of overheating in buildings is excessive solar gain from windows. This is the key to controlling solar gains and maintaining indoor comfort to implement low-energy building design. Sun gains can be limited by an effective shading design. Overheating in buildings can be reduced, and the cooling loads of the building can be reduced by regulating temperature fluctuations. In buildings, by paying attention to window and glass details, it is possible to save energy compared to mechanical cooling by shading. This is a more cost-effective way to control overheating in buildings [7]. Direct radiation falling on the transparent surfaces of buildings adds a significant amount of energy to the energy use of the building. Clear Glass transmits more than $80 \%$ of incoming solar radiation and more than $75 \%$ of visible light. The penetration of solar radiation into indoor spaces may be positive and healthy in some cases, but it can be also extremely unfavorable depending on the climate, season, building function, and occupant activity [5, 8]. Various types of heat-blocking glass have been developed to improve the thermal performance of exterior windows and reduce incoming solar heat gain. The most widely used heat barrier glasses for buildings are Low-emission (low-E) glass and heatabsorbing tinted glass. Low-E glass has a microscopically transparent coating that can reflect most of the near-infrared light while allowing visible (VIR) light to pass through the windows. Sunlight is filtered so that the desired light enters the building. Also, the energy-saving potential of general residential buildings is enormous, especially in high-density cities, due to the lack of energy-saving design and application of energy-saving materials. Despite the high transmittance of Clear Glass, the reflection of solar radiation is low. This makes windows the biggest source of unwanted heat gain. [913]. Solar behavior Clear glass and Low-emissivity (low-E) glass are shown in Fig. 1 and Fig. 2. 


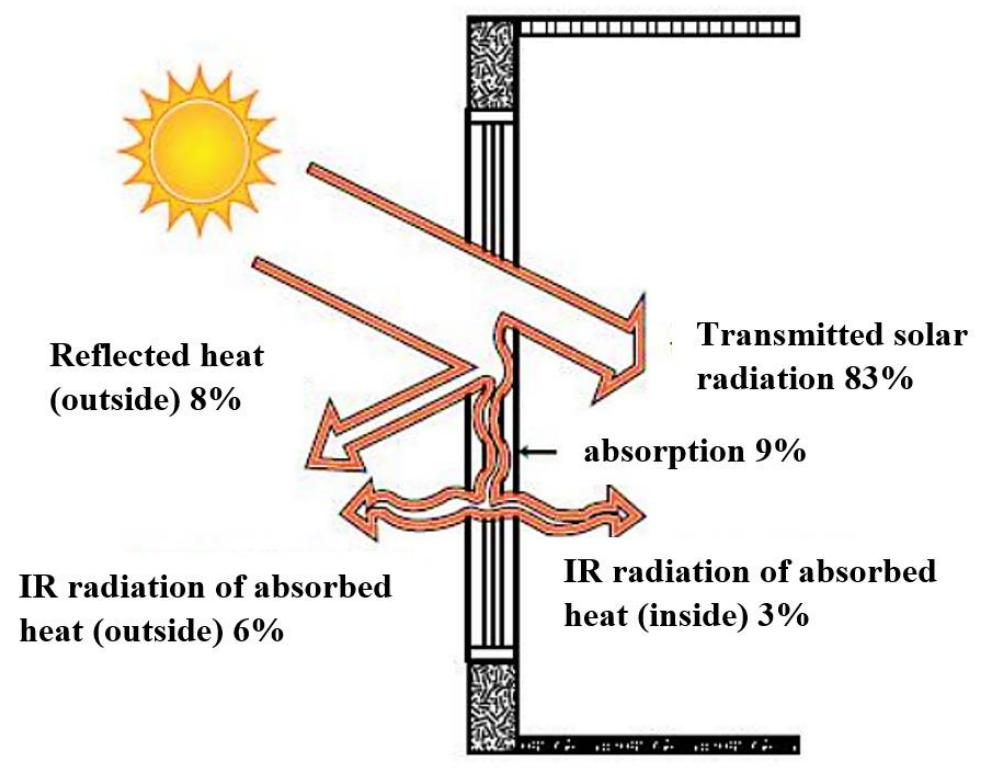

Figure 1. Clear Ordinary Glasses with Highest Solar Transmission [14].

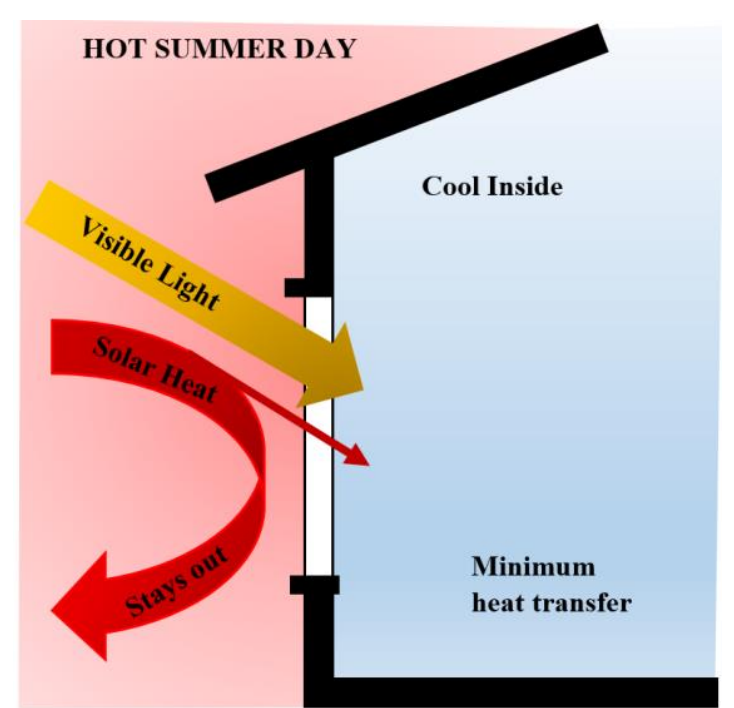

(a)

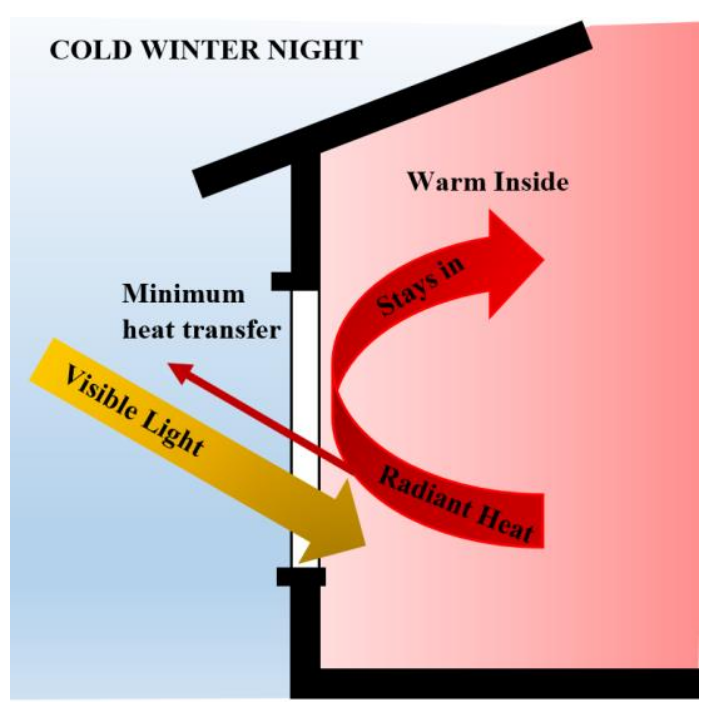

(b)

Figure 2. Solar Heat And visible Transmittance in low-E coated glass in the conditions of (a) summer and (b) winter climates [14].

A low-E coated window saves about $40 \%$ in energy consumption. The Low-E coating also reduces the $\mathrm{U}$ factor while maintaining a high level of visible transmittance [15]. Thermal performance, the minimum or maximum solar heat gain to be included, is dependent on building orientation as well as weather conditions. Therefore, different glazing materials can be designed to prevent unwanted heat gain in a hot climate or to allow solar radiation to transmit indoors in a cold climate $[14,16]$. Performing a time-dependent heat transfer analysis requires complex numerical calculations. Recently, it has become a standard feature of worldwide use of computational numerical tools such as energy thermal simulation software in building design to easily perform these operations [17]. At the beginning of these programs are generalized programs such as EnergyPlus ${ }^{\mathrm{TM}}$ software, OpenStudio, which are promoted through the Energy Efficiency and Renewable Energy Office's Building and Technology Program. These programs have been accepted by the scientific community that performs energy analysis of 
buildings around the world [18]. Energy simulations using this software save cost and time during the design and construction of a building [19]. EnergyPlus ${ }^{\mathrm{TM}}$ software provides handling the transient heat conduction through the building envelope and calculation of thermal loads. One of the main features of the program is its ability to simulate the phase change process of PCMs, whose thermal properties are highly dependent on temperature. Despite the simplicity and the accuracy of the Con-duction Transfer Function (CTF) method, commonly used by EnergyPlus, this method is not able to handle the temperature dependence of the PCM thermal properties. this complexity is solved by the Transmission Finite Difference method (CondFDM), which is also available in the latest versions of the software. The Conduction Finite Difference method (CondFDM), also available in the last versions of the software, allows overcoming this complexity. The CondFDM provides a numerical one-dimensional conduction heat transfer solution $[20,21]$. To take into account the variability of the thermophysical properties of PCM with temperature, the heat transfer through each layer is written by the following heat conduction equation [22].

$$
\begin{gathered}
\rho_{j} c_{P} \frac{\partial T_{j}}{j \partial x_{j}}=\frac{\partial}{\partial x j}\left(k_{j} \frac{\partial T j}{\partial x_{j}}\right) \\
0<x_{j}<e_{j} \\
=1,2, \ldots, N
\end{gathered}
$$

Where $\mathrm{N}$ is the number of the wall layers, $\rho_{j} c_{P}$ and $k$ are density, are density, the specific heat capacity, and the thermal conductivity of the layer, respectively, $e$ is the layer thickness.

Grid size is set automatically where the node spacing " $\Delta \mathrm{x}$ " depends on the thermal diffusivity of the material, on the choice of the time step " $\Delta \mathrm{t}$ " and on a space discretization constant "c" equivalent to the inverse of the Fourier number and controlled by the user

$$
\Delta_{x}=\sqrt{a c \Delta_{t}}
$$

Based on a fully implicit scheme, Equation (1) is formulated for the PCM layer as follows:

$$
\rho C_{P} \Delta_{x} \frac{T_{i}^{m+1}-T_{i}^{m}}{\Delta t}=\left(\frac{k_{i+1}^{m+1}+k_{i}^{m+1}}{2}\right) \frac{T_{i+1}^{m+1}-T_{i}^{m+1}}{\Delta x}+\left(\frac{k_{i-1}^{m+1}+k_{i}^{m+1}}{-2}\right) \frac{T_{i-1}^{m+1}-T_{i}^{m+1}}{\Delta_{x}}
$$

The inclusion of a large area of glazing in facades requires in-depth studies to avoid high energy consumption for cooling and heating during the year [23].

Several studies were performed on thermal and energy performance of office buildings; Gasparella et al, (2011) evaluated the impact of different kinds of glazing systems (two double and two triple glazings), window size (from $16 \%$ to $41 \%$ of the window to floor area ratio), the orientation of the main windowed façade and internal gains [24]. Sadrzadehrafiei et al, (2011) evaluated the energy saving that can be achieved by applying advanced glazing to a typical mid-rise office building in Malaysia, using Integrated Environment Solution (IES) simulation software [25]. Ebrahimpour and Maerefat, (2011) evaluated the effect of advanced glazing and overhangs on the solar energy transmitted into or lost from the room through the fenestration areas for typical residential buildings in Tehran, using EnergyPlus ${ }^{\mathrm{TM}}$ software [26]. Susorova et al., [27] investigated the role of geometry factors, such as window orientation, window to wall ratio, and room width to depth ratio, on building energy performance in a commercial office building. Jelle et al., [28] conducted a state-of-the-art review on high performances fenestration products, ranging from glazing to spacers, frames, etc. In 2016, Amaral et al., [29] presented a methodology for the parametric study of a window optimal dimension, based on the thermal performance of a reference room located in the climate region of Coimbra, Portugal. Zekraoui and Zemmouri investigated the effect of orientation and façades openness and glazing type on global energy consumption in typical offices under the specific climate of present areas in the south of Algeria using EnergyPlus ${ }^{\mathrm{TM}}$ software [30]. Alghoul et al., evaluated the influence of window to wall ratio (WWR) and 
window orientation (WO) on cooling, heating, and total energy consumption using EnergyPlus ${ }^{\mathrm{TM}}$ software [23]. In 2019, Aram and Alibaba, analyzed the optimal single-story office building model with a corner atrium type according to four different atrium orientations and five different window opening ratios [31]. In a most recent study, Pilechiha et al., investigated the effect of different parameters of the double glazed window, such as the type of glass, as well as the filling gas between the double glazed windows with four different air distances [32].

From the literature review, it is evident that the window is the most vital part of a building to minimize heat gain/loss. The important thing to know is in which orientation heat gain/loss will be maximum and what measures should be applied to reduce heat gain/loss without affecting the daylight harvesting through windows [33].

Despite many studies on the thermal efficiency of the buildings decision on accurate efficiency building materials requires further research. The evaluation of baseline scenarios is important as different glazing scenarios are compared in buildings and as a result, it determines the minimum energy performance in buildings. Therefore, the type of glass that gives the best performance can be given priority in the glass selection of office buildings, and thus energy efficiency can be achieved in office buildings. This situation reveals the importance of the study. Finally, this study demonstrates how minimal energy use can be integrated into office buildings, thus enabling an iterative performance-based design process.

\section{ENERGY USE IN OFFICE BUILDINGS}

Especially, in buildings in regions with significant thermal emission and solar radiation; choosing the building system that contributes the most to the thermal comfort conditions of the building before using heating or air conditioning systems and performing time-dependent heat transfer analysis is so important to minimize energy consumption in buildings [34].

The methodology of this study consists of four steps. In the first step, it was formed with a $4 \mathrm{~mm}$ thick flat glass. Then, the base model was changed in the second step to account for how much the glass properties affected the energy factors of the structure. Fig. 1 illustrates the combinations of windows. In step three, the total and hourly energy requirements of the space were extracted from the simulation to study the effect of glazing window material. Finally, the effect of glazing material on energy-saving was categorized according to its applicability for the suggested suitable glazing window factors for different orientations. The model geometry was drawn and created by SketchUp software. Then OpenStudio was used to modify model properties, including structure, materials, usage, internal loads, and schedules. Also, EnergyPlus ${ }^{\mathrm{TM}}$ software was used to perform an annual energy simulation for the operating conditions with different parameters. Eventually, the results obtained are presented in OpenStudio and prepared in a suitable format. Fig 3 provides an overall scheme of the modeling and simulation process that is adopted in this work. 


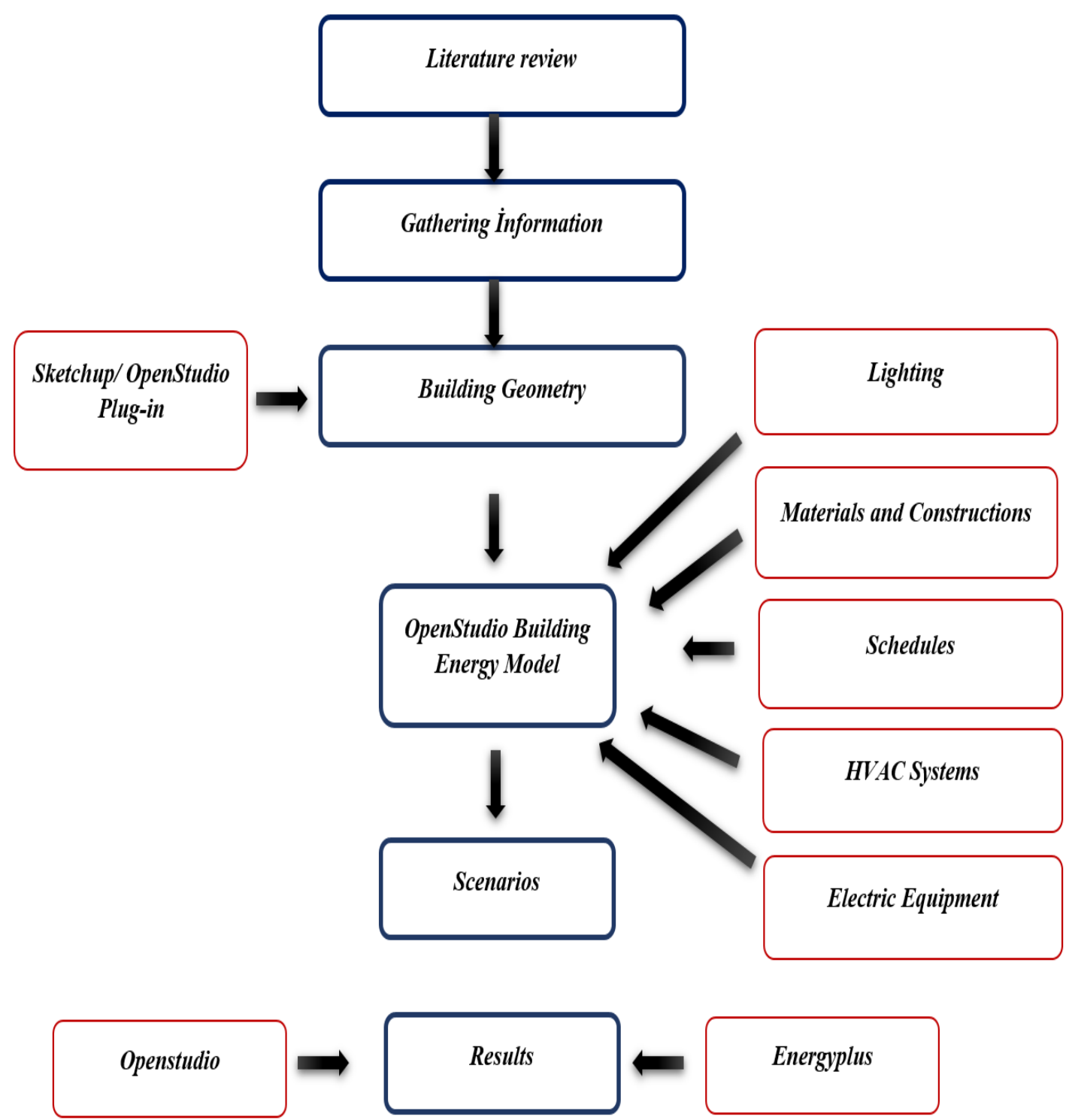

Figure 3. Overall building energy modeling, simulation, and retrofit assessment scheme.

To determine the cooling and heating schedule for each unit in the office and office, the necessary definitions were made from the Openstudio "schedule" tab, and the "heating" and "cooling" program for the working office was created for the whole measurement year. The introduction of dynamic windows enables more effective use of available resources such as sunlight and daylight in terms of energy demand requirements and occupant comfort. Previous research has been done on dynamic fenestration technologies to determine their importance concerning energy consumption and occupant comfort. The results show the potential of dynamic fenestration components for the reduction in cooling and lighting demand [35], [36].

\section{CASE.STUDY}

\subsection{Description of the Building and Climate Data}

In the present study, a typical office building has been selected as the case study for evaluating the energy performance of windows Glazing parameters. The office basement plan is given in Fig. 4, It can be seen that the house has a breakroom, offices, vending, conference, Elec/ Mech room, IT room, Lobby, 
corridor, storage toilet, and WC. The area of conditioned space is $118.64 \mathrm{~m}^{2}$. Electric equipment consists of the normal equipment for an office like printers, computers, microwaves, etc. The usage of this equipment is adjusted according to the needs of an office for a year, depending on the season and time of the day.
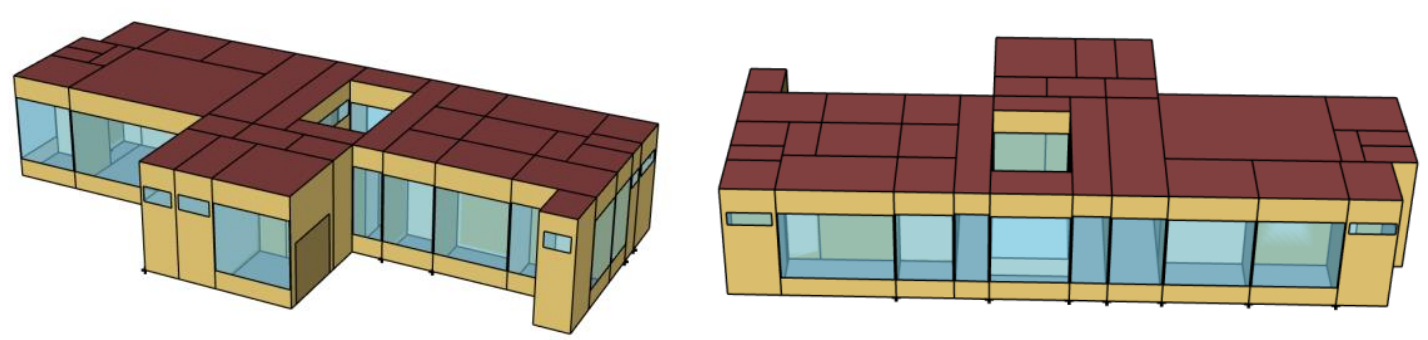

Figure 4. The simulated office building

The office is occupied from 8:00 am to 6:00 pm Monday through Friday. People sit at their desks with their sides facing the windowed wall. Internal loads associated with electrical equipment are digitized taking into account personal computers, monitors, laser printers, and copiers with constant average power over their lifetime. The office building has a chiller, which works in conjunction with a variable volume cooling system and has an external ventilation unit for the building floor as well as heat recovery. For this reason, there is a heat pump system in the building with VRF and an outdoor ventilation unit in total. In OpenStudio modeling, electrical equipment, lighting, cooling, and heating of office spaces, the people schedule in the office also were taken into account. VRF systems for air-conditioning and a dedicated outdoor air system for ventilation are used in the office building

To determine the energy performance of such study of office buildings on the number of office buildings in Turkey and which has the highest number of figures from the study of pain has been chosen Istanbul. Summers in Istanbul are warm, humid, dry, and clear; winters are long, cold, windy, and partly cloudy. Throughout the year, the temperature typically ranges from $3^{\circ} \mathrm{C}$ to $30^{\circ} \mathrm{C}$ and is rarely below $-1^{\circ} \mathrm{C}$ or above $32^{\circ} \mathrm{C}$ [37]. Wet and Dry bulb temperature and the Monthly Average Temperature of Istanbul is shown in Fig 5. and Fig 6, respectively. A typical air-conditioned office building, located in Istanbul, has been analyzed for the whole year. The simulation runs from 1 January to 31 December.

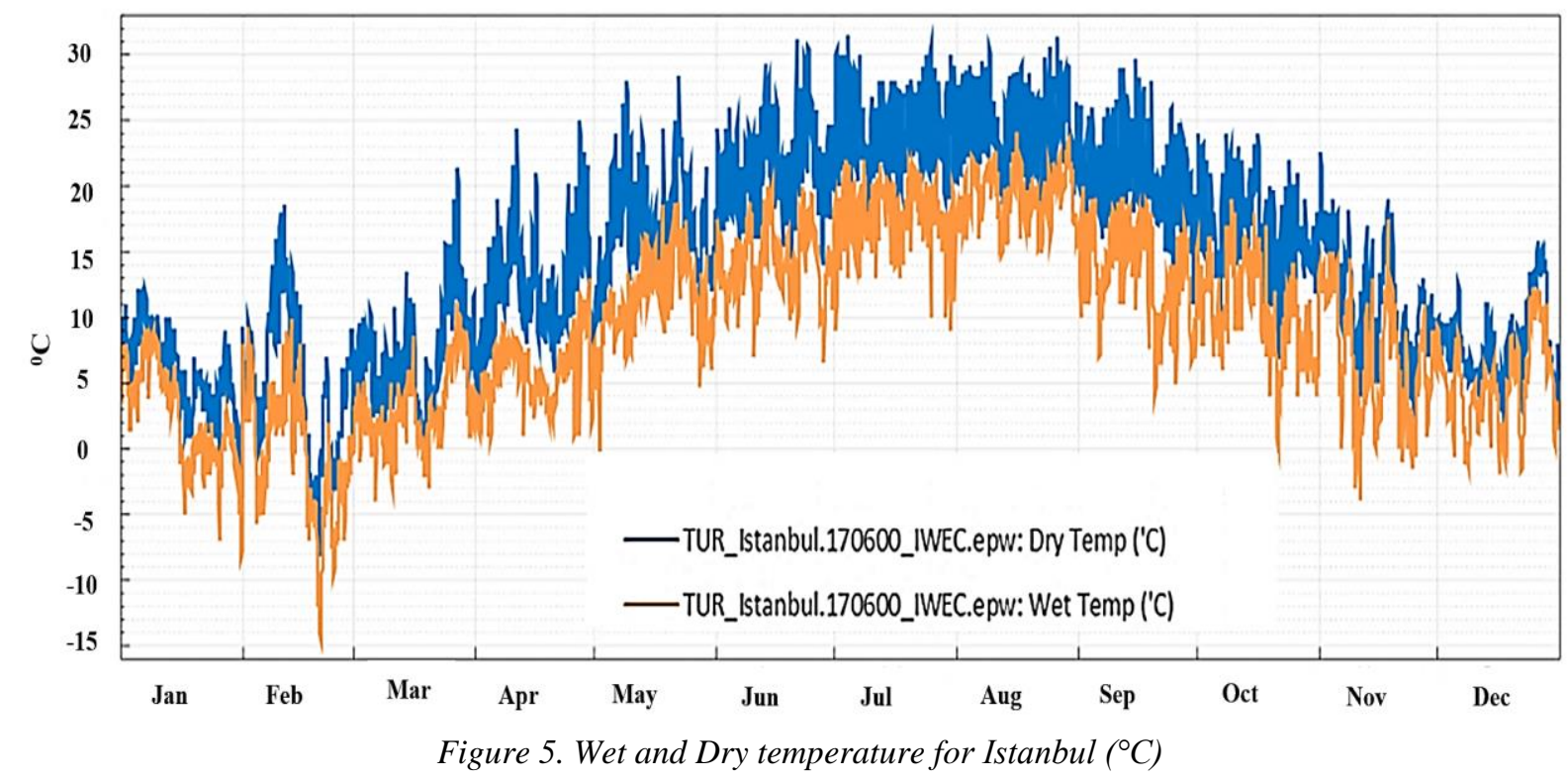

Istanbul city temperature decreases to -15 degrees during the winter months for wet temperature. Dry Temperature is higher than Wet temperature both in summer and winter. The Glazing effects of the 
office model in winter increase the office zone temperature and decrease the heating energy consumption. As windows, doors and other ventilation areas in the office are closed in winter, a greenhouse effect is created.

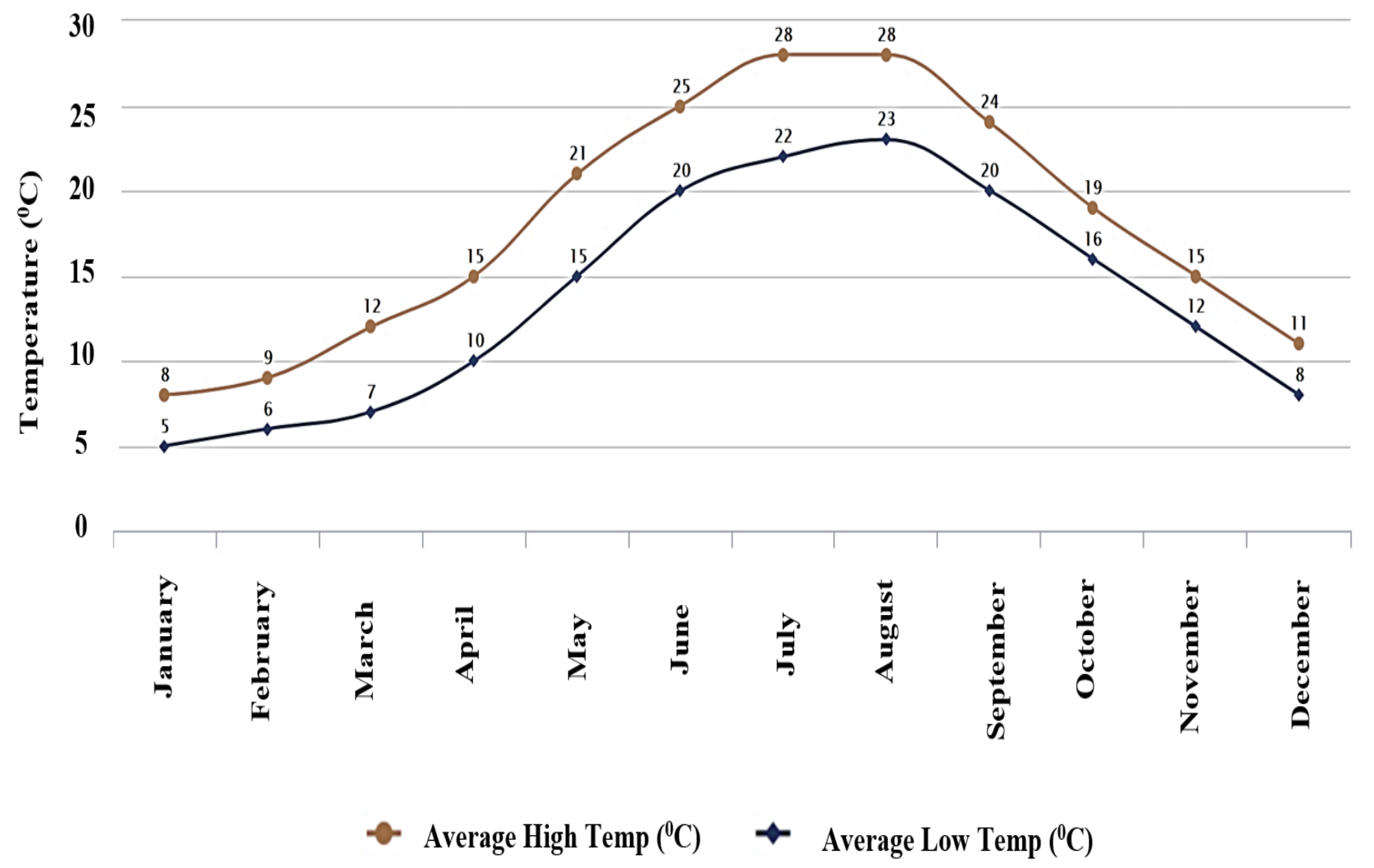

Figure 6. Monthly Average Temperature graph for Istanbul $\left({ }^{\circ} \mathrm{C}\right)$ [37]

On the other hand, average High and average low temperatures were also compared during the year. As shown in Fig 5, the average low temperature during the winter ranged from $5^{\circ} \mathrm{C}$ to $8^{\circ} \mathrm{C}$; however, the average high temperature ranged from $8^{\circ} \mathrm{C}$ to $15^{\circ} \mathrm{C}$ during the same time interval. On average, Istanbul city's average high temperature is approximately $5^{\circ} \mathrm{C}$ higher than the low high temperature in winter.

The energy demands of the heating, cooling, and lighting (main technical systems) have been evaluated. Large windows are often used in office buildings to make more use of daylight. Table 1 shows the case studies performed in the sample office. The energy performance results were compared for different glazing windows and air materials.

Table 1. Combination for case study.

\begin{tabular}{|c|c|c|c|c|c|c|}
\hline $\begin{array}{l}\text { Climate/ } \\
\text { City }\end{array}$ & Code & $\begin{array}{c}\text { Glazing Windows } \\
\text { Material }\end{array}$ & $\begin{array}{c}\text { Gas Window } \\
\text { Material }\end{array}$ & $\begin{array}{c}\text { Wall } \\
\text { Composition }\end{array}$ & $\begin{array}{c}\text { Roof } \\
\text { Composition }\end{array}$ & $\begin{array}{c}\text { Floor } \\
\text { Composition }\end{array}$ \\
\hline Istanbul & $\begin{array}{l}\text { Glazing A } \\
\text { Glazing B } \\
\text { Glazing C } \\
\text { Glazing D }\end{array}$ & $\begin{array}{l}4 \mathrm{~mm} \text { Glass } \\
6 \mathrm{~mm} \text { Glass } \\
4 \mathrm{~mm} \text { LE Glass } \\
6 \mathrm{~mm} \text { LE Glass }\end{array}$ & $\begin{array}{l}\text { Air } 6 \mathrm{~mm} \\
\text { Air } 13 \mathrm{~mm}\end{array}$ & $\begin{array}{l}\text { Building } \\
\text { Materials }\end{array}$ & Roof Materials & Floor Materials \\
\hline
\end{tabular}

\subsection{Material Properties}

A design can be developed using a certain combination of materials and passive systems to increase thermal comfort in buildings. Computer simulation techniques stand out as very powerful tools to accurately analyze the thermal performance of buildings and determine the current and future behavior of the project. To perform a dynamic simulation of a building, a large amount of information is needed about the geometry of the building, weather data, and the thermal and optical properties of materials. 
The properties of building materials represent critical information due to their impact on the energy balance of the building [2], [38].

The physical properties of the floor, as well as the materials and constructions used in the model, walls, ceiling, windows, doors, are presented in detail below. Tables 2- 8 show the thermal and optical properties of the office building construction systems applied in this study.

Table 2. Characteristics of building materials used in base case model.

\begin{tabular}{|c|c|c|c|c|c|c|c|c|c|c|}
\hline & Roughness & $\begin{array}{l}\text { Thickness } \\
(\mathrm{m})\end{array}$ & $\begin{array}{l}\text { Conductivity } \\
(\mathrm{W} / \mathrm{m} \cdot \mathrm{k})\end{array}$ & $\begin{array}{l}\text { Density } \\
\left(\mathrm{kg} / \mathrm{m}^{3}\right)\end{array}$ & $\begin{array}{l}\text { Specific Heat } \\
(\mathrm{J} / \mathrm{kgK})\end{array}$ & $\begin{array}{l}\text { Thermal } \\
\text { Absorpt. }\end{array}$ & $\begin{array}{c}\text { Solar } \\
\text { Absorpt. }\end{array}$ & $\begin{array}{l}\text { Visible } \\
\text { Absorpt. }\end{array}$ & $\begin{array}{l}\text { U-Value } \\
\left(\mathrm{W} / \mathrm{m}^{2}-\mathrm{K}\right)\end{array}$ & Reflectance \\
\hline \multirow{4}{*}{$\begin{array}{l}\text { Outside } \\
\text { Layer }\end{array}$} & 1 IN Stucco & 0.0253 & 0.6918 & 1858 & 837 & 0.9 & 0.92 & 0.92 & & \\
\hline & $\begin{array}{ll}\text { 8IN Concrete } & \text { Medium- } \\
\text { HW } & \text { Rough }\end{array}$ & 0.2033 & 1.7296 & 2243 & 837 & 0.9 & 0.65 & 0.65 & & \\
\hline & $\begin{array}{ll}\text { Wall } & \text { Medium- } \\
\text { Insulation } & \text { Rough }\end{array}$ & 0.0794 & 0.0432 & 91 & 837 & 0.9 & 0.5 & 0.5 & & \\
\hline & $1 / 2$ IN Gypsum Smooth & 0.0127 & 0.16 & 784.9 & 830 & 0.9 & 0.4 & 0.4 & & \\
\hline \multicolumn{11}{|l|}{$\begin{array}{l}\text { Inside } \\
\text { Layer }\end{array}$} \\
\hline Total & & 0.3207 & & & & & & & 0.45 & 0.08 \\
\hline
\end{tabular}

Table 3. Roof material properties.

\begin{tabular}{|c|c|c|c|c|c|c|c|c|c|c|c|}
\hline & \multicolumn{2}{|c|}{ Roughness } & \multirow{2}{*}{$\begin{array}{c}\text { Thickness } \\
(\mathrm{m})\end{array}$} & \multirow{2}{*}{$\begin{array}{l}\begin{array}{c}\text { Conductivity } \\
\text { (W/m.k) }\end{array} \\
0.16\end{array}$} & \multirow{2}{*}{$\begin{array}{l}\begin{array}{l}\text { Density } \\
\left(\mathrm{kg} / \mathrm{m}^{3}\right)\end{array} \\
1121.29\end{array}$} & \multirow{2}{*}{$\begin{array}{c}\text { Specific } \\
\text { Heat } \\
(\mathrm{J} / \mathrm{kgK})\end{array}$} & \multirow{2}{*}{$\begin{array}{l}\text { Thermal } \\
\text { Absorpt. } \\
0.9\end{array}$} & \multirow{2}{*}{$\begin{array}{l}\begin{array}{c}\text { Solar } \\
\text { Absorpt. }\end{array} \\
0.7\end{array}$} & \multirow{2}{*}{$\begin{array}{l}\text { Visible } \\
\text { Absorpt. } \\
0.7\end{array}$} & \multirow[t]{2}{*}{$\begin{array}{l}\text { U-Value } \\
\left(\mathrm{W} / \mathrm{m}^{2} \mathrm{~K}\right)\end{array}$} & \multirow[t]{2}{*}{ Reflectance } \\
\hline & $\begin{array}{c}\text { Roof } \\
\text { Membrane }\end{array}$ & $\begin{array}{l}\text { Very- } \\
\text { Rough }\end{array}$ & & & & & & & & & \\
\hline \multirow[t]{2}{*}{$\begin{array}{l}\text { Outside } \\
\text { Layer }\end{array}$} & $\begin{array}{c}\text { Roof } \\
\text { Insulation }\end{array}$ & $\begin{array}{l}\text { Medium- } \\
\text { Rough }\end{array}$ & 0.2105 & 0.049 & 265 & 836.8 & 0.9 & 0.7 & 0.7 & & \\
\hline & $\begin{array}{c}\text { Metal } \\
\text { Decking }\end{array}$ & $\begin{array}{l}\text { Medium- } \\
\text { Smooth }\end{array}$ & 0.0015 & 45.006 & 7680 & 418.4 & 0.9 & 0.6 & 0.6 & & \\
\hline \multicolumn{12}{|l|}{$\begin{array}{l}\text { Inside } \\
\text { Layer }\end{array}$} \\
\hline Total & & & 0.2215 & & & & & & & 0.223 & 0.3 \\
\hline
\end{tabular}

Table 4. Inside door material properties.

\begin{tabular}{|c|c|c|c|c|c|c|c|c|c|}
\hline & \multicolumn{2}{|c|}{ Roughness } & $\begin{array}{c}\text { Thickness } \\
\text { (m) }\end{array}$ & $\begin{array}{l}\text { Conductivity } \\
\text { (W/m.k) }\end{array}$ & $\begin{array}{l}\text { Density } \\
\left(\mathrm{kg} / \mathrm{m}^{3}\right)\end{array}$ & $\begin{array}{c}\text { Specific Heat } \\
(\mathrm{J} / \mathrm{kgK})\end{array}$ & $\begin{array}{c}\text { Thermal } \\
\text { Absorptance }\end{array}$ & $\begin{array}{c}\text { Solar } \\
\text { Absorptance }\end{array}$ & $\begin{array}{c}\text { Visible } \\
\text { Absorptance }\end{array}$ \\
\hline $\begin{array}{l}\text { Outside } \\
\text { Layer }\end{array}$ & $\begin{array}{c}\text { G05 } \\
2 \mathrm{~mm} \\
\text { wood }\end{array}$ & $\begin{array}{l}\text { Medium } \\
\text { Smooth }\end{array}$ & 0.0254 & 0.15 & 608 & 1630 & 0.9 & 0.5 & 0.5 \\
\hline $\begin{array}{l}\text { Inside } \\
\text { Layer }\end{array}$ & & & & & & & & & \\
\hline
\end{tabular}

Table 5. Outside door material properties.

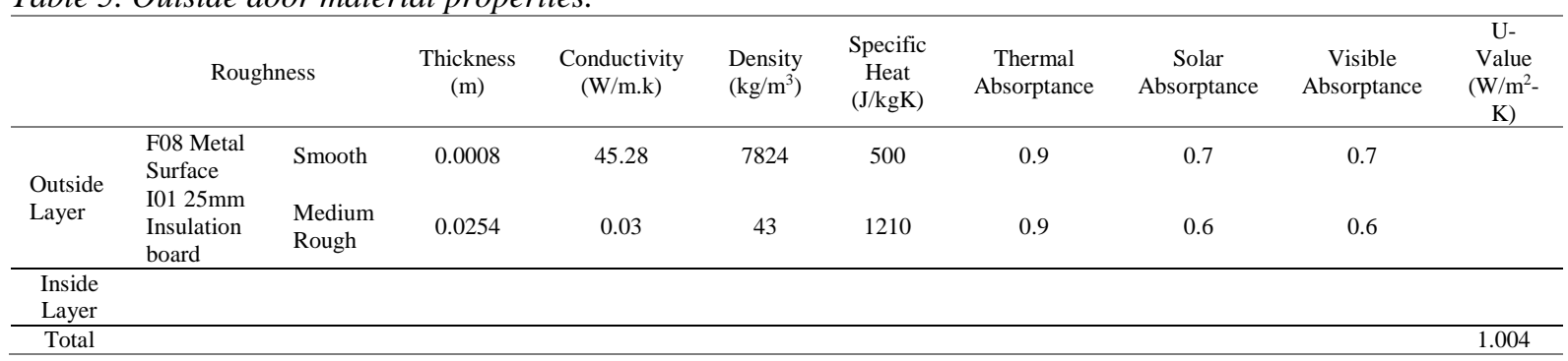

Table 6. Floor material properties.

\begin{tabular}{|c|c|c|c|c|c|c|c|c|c|c|c|}
\hline & Roug & hess & $\begin{array}{l}\text { Thickness } \\
\text { (m) }\end{array}$ & $\begin{array}{l}\text { Conductivity } \\
(\mathrm{W} / \mathrm{m} \cdot \mathrm{k})\end{array}$ & $\begin{array}{l}\text { Density } \\
\left(\mathrm{kg} / \mathrm{m}^{3}\right)\end{array}$ & $\begin{array}{c}\text { Specific } \\
\text { Heat } \\
(\mathrm{J} / \mathrm{kgK})\end{array}$ & $\begin{array}{l}\text { Thermal } \\
\text { Absorpt. }\end{array}$ & $\begin{array}{c}\text { Solar } \\
\text { Absorpt. }\end{array}$ & $\begin{array}{c}\text { Visible } \\
\text { Absorpt. }\end{array}$ & $\begin{array}{l}\text { U-Value } \\
\left(\mathrm{W} / \mathrm{m}^{2} \mathrm{~K}\right)\end{array}$ & Reflectance \\
\hline \multirow{2}{*}{$\begin{array}{l}\text { Outside } \\
\text { Layer }\end{array}$} & $\begin{array}{l}4 \mathrm{HW} \\
\text { Concrete }\end{array}$ & Rough & 0.1016 & 1.311 & 2240 & 836.8 & 0.9 & 0.85 & 0.85 & & \\
\hline & CP Pad & Smooth & - & - & - & 0 & 0.9 & 0.8 & 0.8 & & \\
\hline \multicolumn{12}{|l|}{$\begin{array}{l}\text { Inside } \\
\text { Layer }\end{array}$} \\
\hline Total & & & & & & & & & & 0.85 & 0.15 \\
\hline
\end{tabular}


Table 7. Properties of glazing window materials of font E.P.

\begin{tabular}{|c|c|c|c|c|c|c|c|}
\hline Name & $\begin{array}{l}\text { Optical Data } \\
\text { Type }\end{array}$ & $\begin{array}{l}\text { Thickness } \\
\text { (m) }\end{array}$ & $\begin{array}{c}\text { Solar } \\
\text { Transmittance at } \\
\text { Normal Incidence }\end{array}$ & $\begin{array}{l}\text { Front Side Solar } \\
\text { Reflectance at } \\
\text { Normal Incidence }\end{array}$ & $\begin{array}{c}\text { Back Side Solar } \\
\text { Reflectance at } \\
\text { Normal } \\
\text { Incidence }\end{array}$ & $\begin{array}{c}\text { Visible } \\
\text { Transmittance at } \\
\text { Normal Incidence }\end{array}$ & $\begin{array}{l}\text { Front Side } \\
\text { Visible } \\
\text { Reflectance } \\
\text { at Normal } \\
\text { Incidence } \\
\end{array}$ \\
\hline Glass $4 \mathrm{~mm}$ & $\begin{array}{l}\text { Spectral } \\
\text { Average }\end{array}$ & 0.004 & 0.837 & 0.075 & 0.075 & 0.898 & 0.081 \\
\hline Glass $6 \mathrm{~mm}$ & $\begin{array}{l}\text { Spectral } \\
\text { Average }\end{array}$ & 0.006 & 0.775 & 0.071 & 0.071 & 0.881 & 0.08 \\
\hline $\begin{array}{l}\text { Glass LE } \\
4 \mathrm{~mm}\end{array}$ & $\begin{array}{l}\text { Spectral } \\
\text { Average }\end{array}$ & 0.004 & 0.894 & 0.079 & 0.079 & 0.911 & 0.082 \\
\hline $\begin{array}{l}\text { Glass LE } \\
6 \mathrm{~mm}\end{array}$ & $\begin{array}{l}\text { Spectral } \\
\text { Average }\end{array}$ & 0.006 & 0.600 & 0.170 & 0.220 & 0.840 & 0.055 \\
\hline Name & $\begin{array}{c}\text { Back Side } \\
\text { Visible } \\
\text { Reflectance at } \\
\text { Normal } \\
\text { Incidence }\end{array}$ & $\begin{array}{l}\text { Infrared } \\
\text { Transmittance } \\
\text { at Normal } \\
\text { Incidence }\end{array}$ & $\begin{array}{c}\text { Front Side } \\
\text { Infrared } \\
\text { Hemispherical } \\
\text { Emissivity }\end{array}$ & $\begin{array}{c}\text { Back Side Infrared } \\
\text { Hemispherical } \\
\text { Emissivity }\end{array}$ & $\begin{array}{l}\text { Conductivity } \\
(\mathrm{W} / \mathrm{mK})\end{array}$ & $\begin{array}{l}\text { Dirt Correction } \\
\text { Factor for Solar } \\
\text { and Visible } \\
\text { Transmittance }\end{array}$ & $\begin{array}{c}\text { Solar } \\
\text { Diffusing }\end{array}$ \\
\hline Glass 4mm & 0.081 & 0 & 0.84 & 0.84 & 0.9 & 1 & off \\
\hline Glass $6 \mathrm{~mm}$ & 0.08 & 0 & 0.84 & 0.84 & 0.9 & 1 & off \\
\hline $\begin{array}{c}\text { Glass LE } \\
4 \mathrm{~mm}\end{array}$ & 0.082 & 0 & 0.84 & 0.84 & 0.9 & 1 & off \\
\hline $\begin{array}{c}\text { Glass LE } \\
6 \mathrm{~mm}\end{array}$ & 0.078 & 0 & 0.84 & 0.1 & 0.9 & 1 & off \\
\hline
\end{tabular}

Table 8. Properties of Gas window materials of font E.P.

\begin{tabular}{lcc}
\hline Name & Gas Type & Thickness $(\mathrm{m})$ \\
\hline Air $13 \mathrm{~mm}$ & Air & 0.0127 \\
Air $6 \mathrm{~mm}$ & Air & 0.0063 \\
\hline
\end{tabular}

\section{ANALYSIS RESULTS}

Based on the Glazing type described in section 4, the annual electricity consumption for the mid-rise office building was calculated from the hourly electricity consumption predicted by software. The simulation was run from $1^{\text {st }}$ January up to $31^{\text {st }}$ December.

Computer simulation results for each configuration were compared taking into account windows glazing with different material characteristics. When considering the results of the simulations for the four different types of different glazing retrofitted schools, an overall comparison is performed between estimated, dynamic simulated.

Below are the results of the simulation in terms of energy consumption according to four different window combinations of the entire building, as well as the results under categories for the entire simulation period. If offices are compared; it can be seen that Offices, has Glazing D window material, are using less energy than others. This can be seen by comparing Figs $7-11$. The figures show monthly energy consumption and load category in bar graph form. 


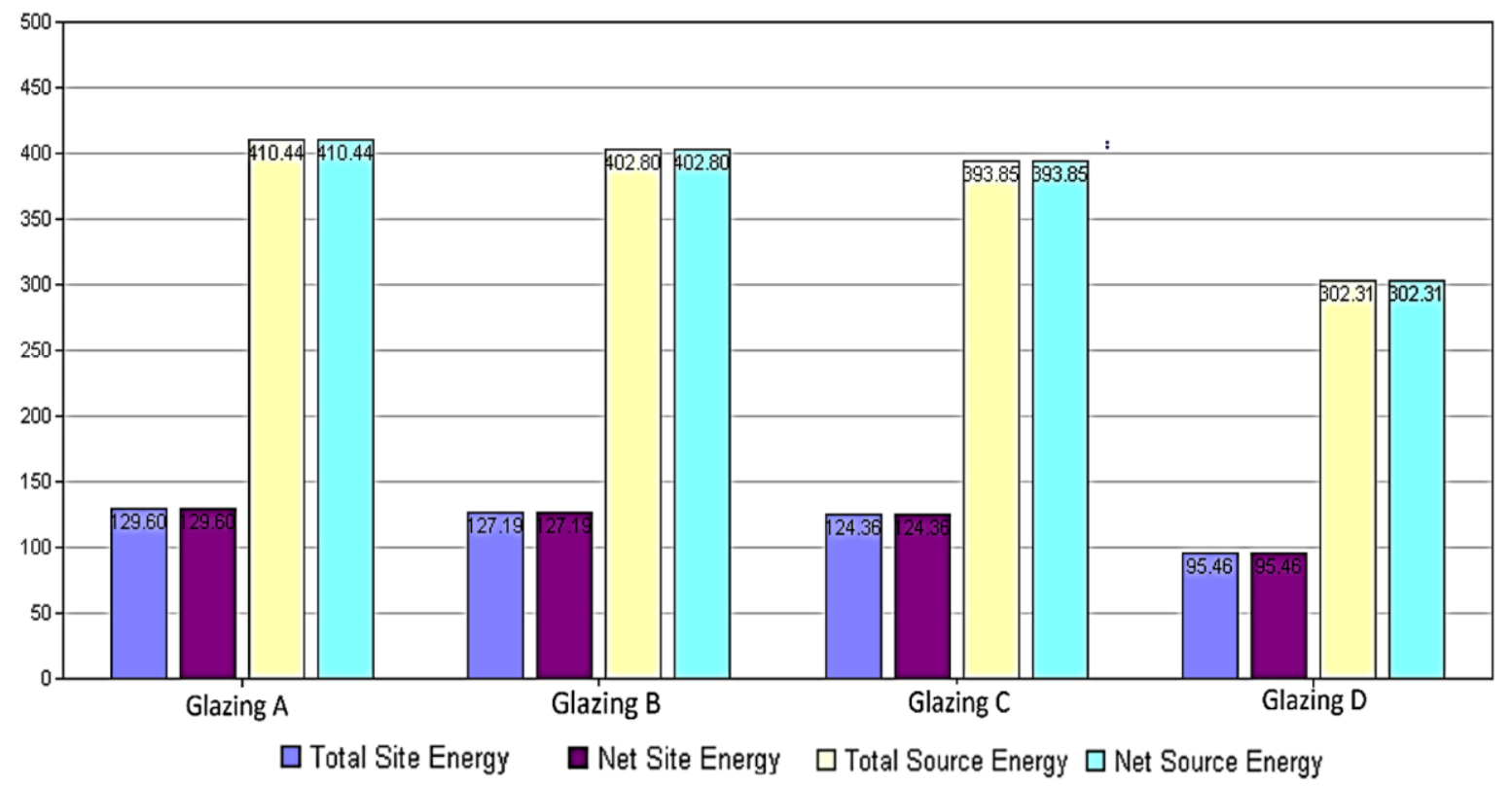

Figure 7. Annual energy performance summary.

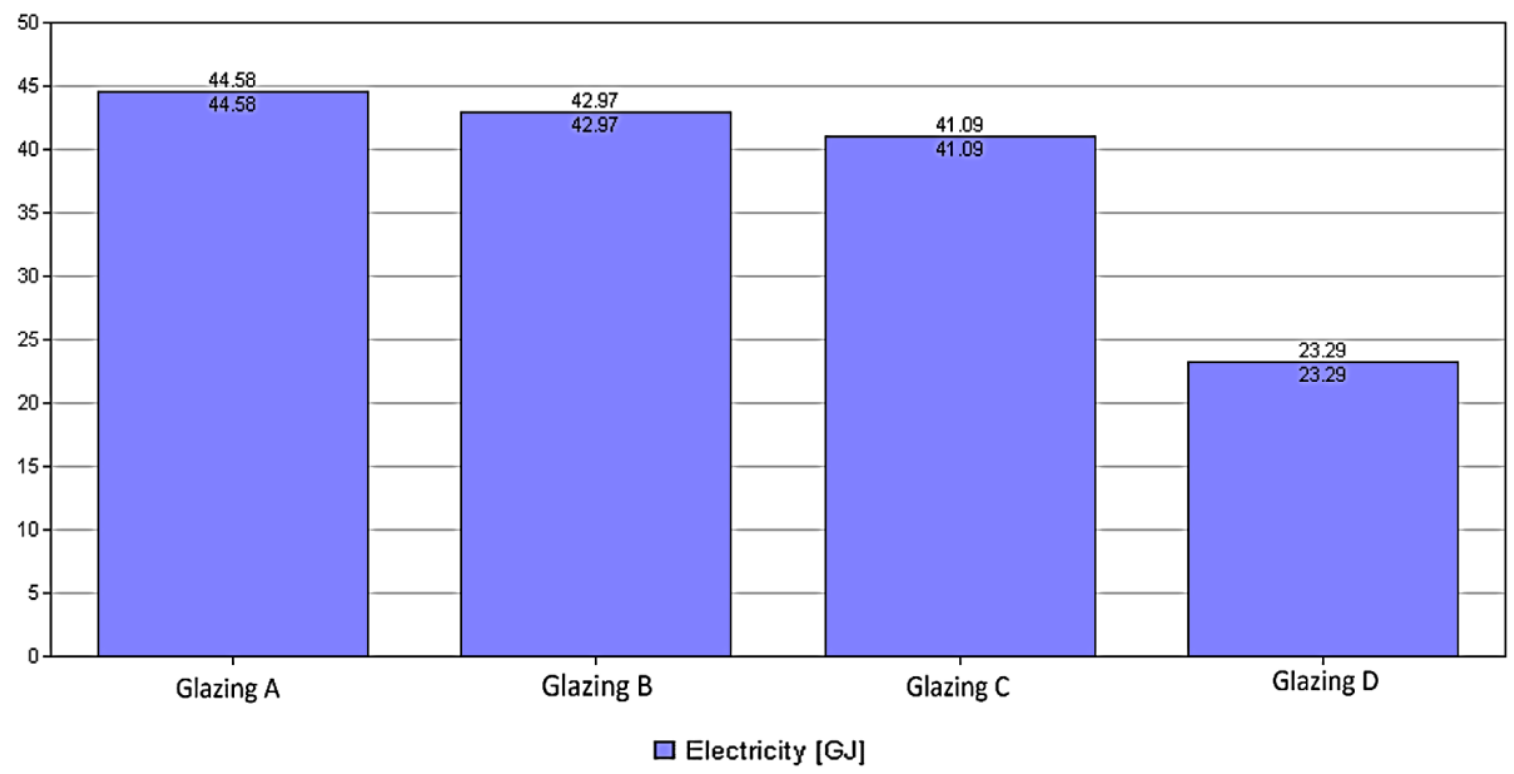

Figure 8. Annual end uses performance summary.

Sadrzadehrafiei et al. (2011) found the total energy consumption of the building as air conditioning (58\%), lighting and cooling (21\%), equipment (21\%), respectively [25]. These values are similar to the results obtained from this study and are given in Fig 9. 


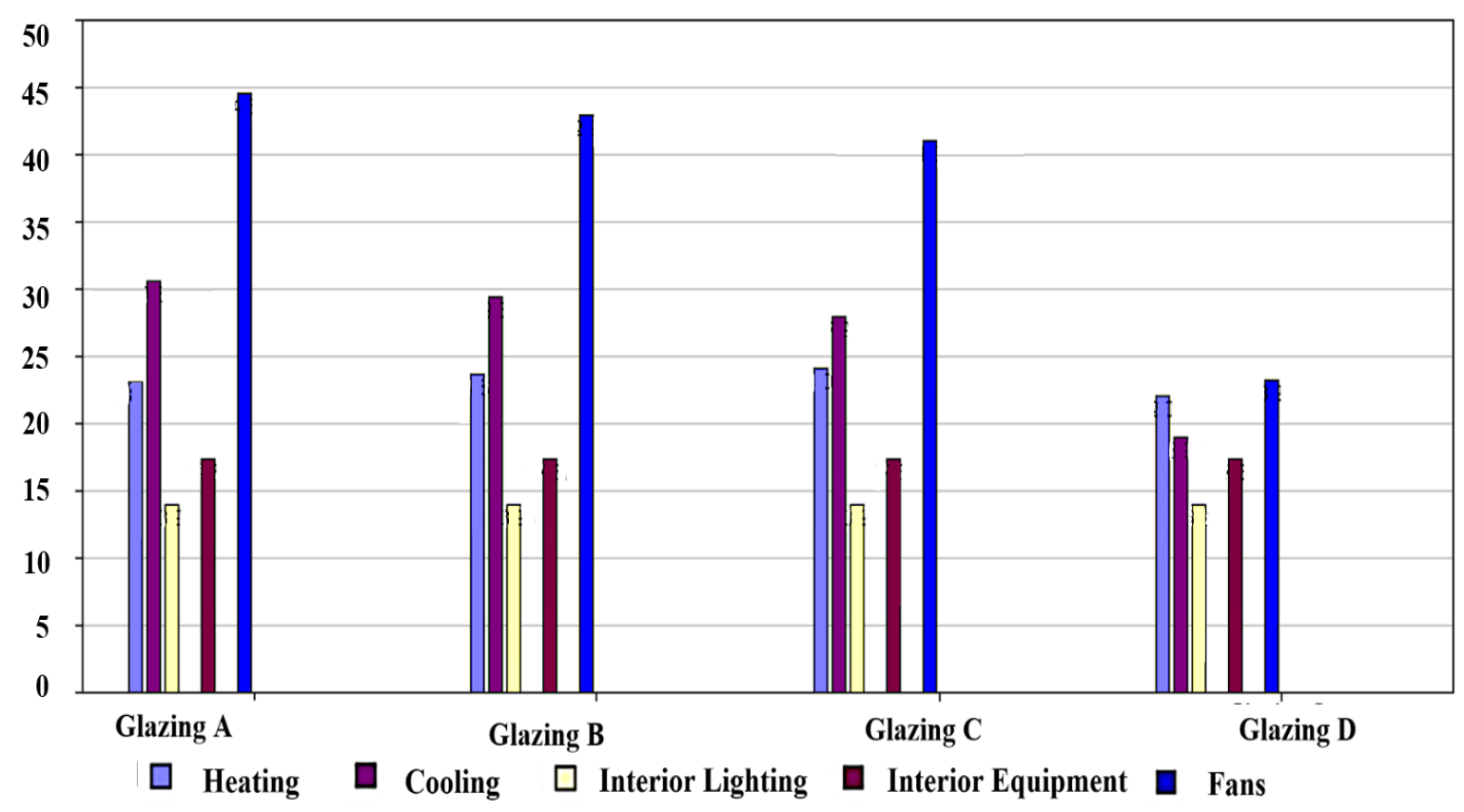

Figure 9. Annual electricity performance summary.

When offices with Glazing A are compared it can be seen offices with Glazing B are using 0.52 GJ more energy for heating. If Glazing C is compared with Glazing D; Glazing D needs 2.08 GJ more energy for heating. Considering the energy requirement for cooling and fan in $4 \mathrm{~mm}$ thick windows $\mathrm{A}$ and $\mathrm{B}$, window $B$ with emission feature requires less energy, the same applies to $C$ and $D$ windows of $6 \mathrm{~mm}$ thickness.

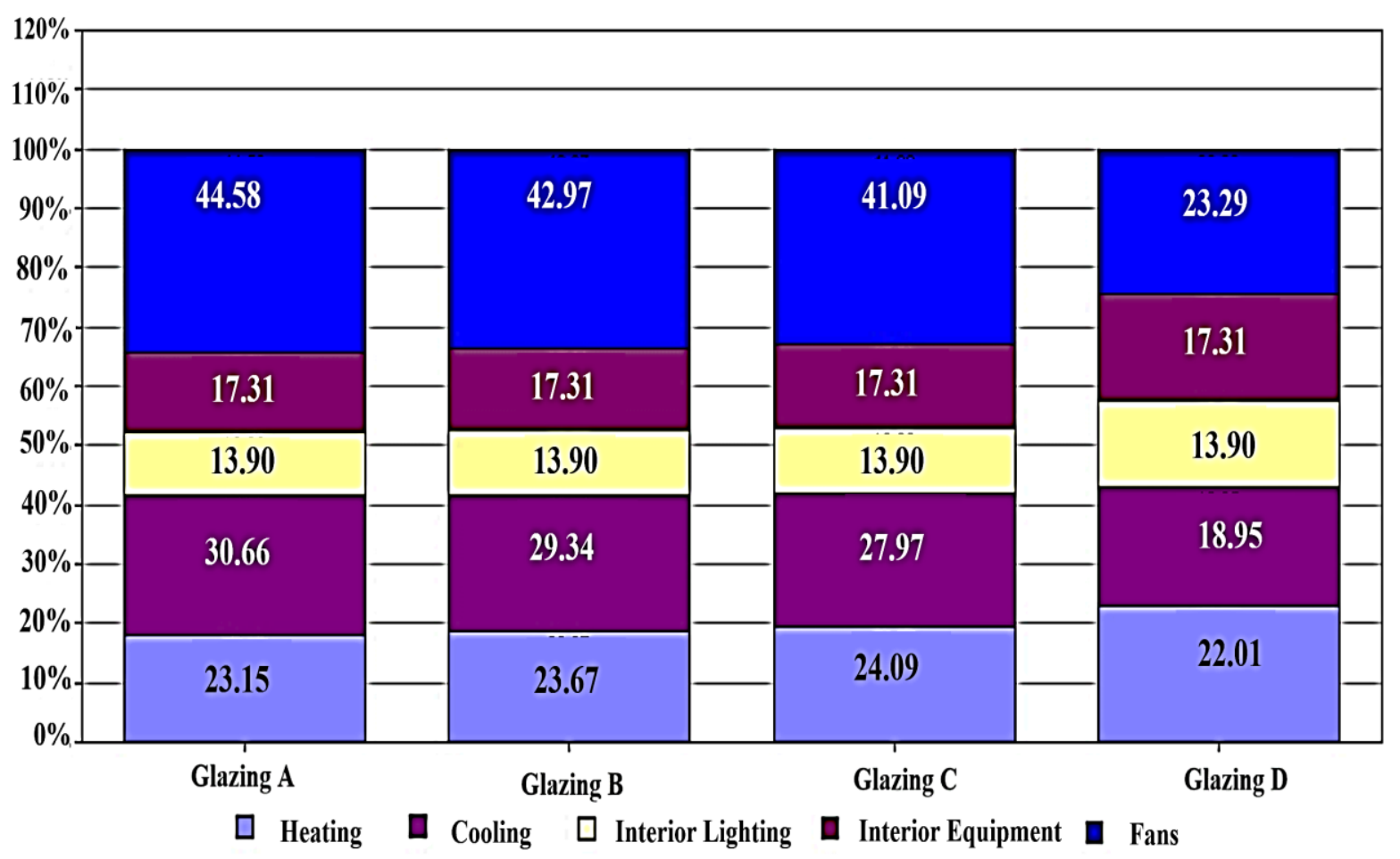

Figure 10. Electricity performance summary.

If the effect of glass types on the annual energy consumption performance of office buildings is evaluated, it is seen that the glass difference affects the fan systems the most, thus directly affecting the 
heating and cooling rates in the buildings. Besides, it can be seen from Figs 10 and 11 that the glass types used in the study do not affect interior lighting.

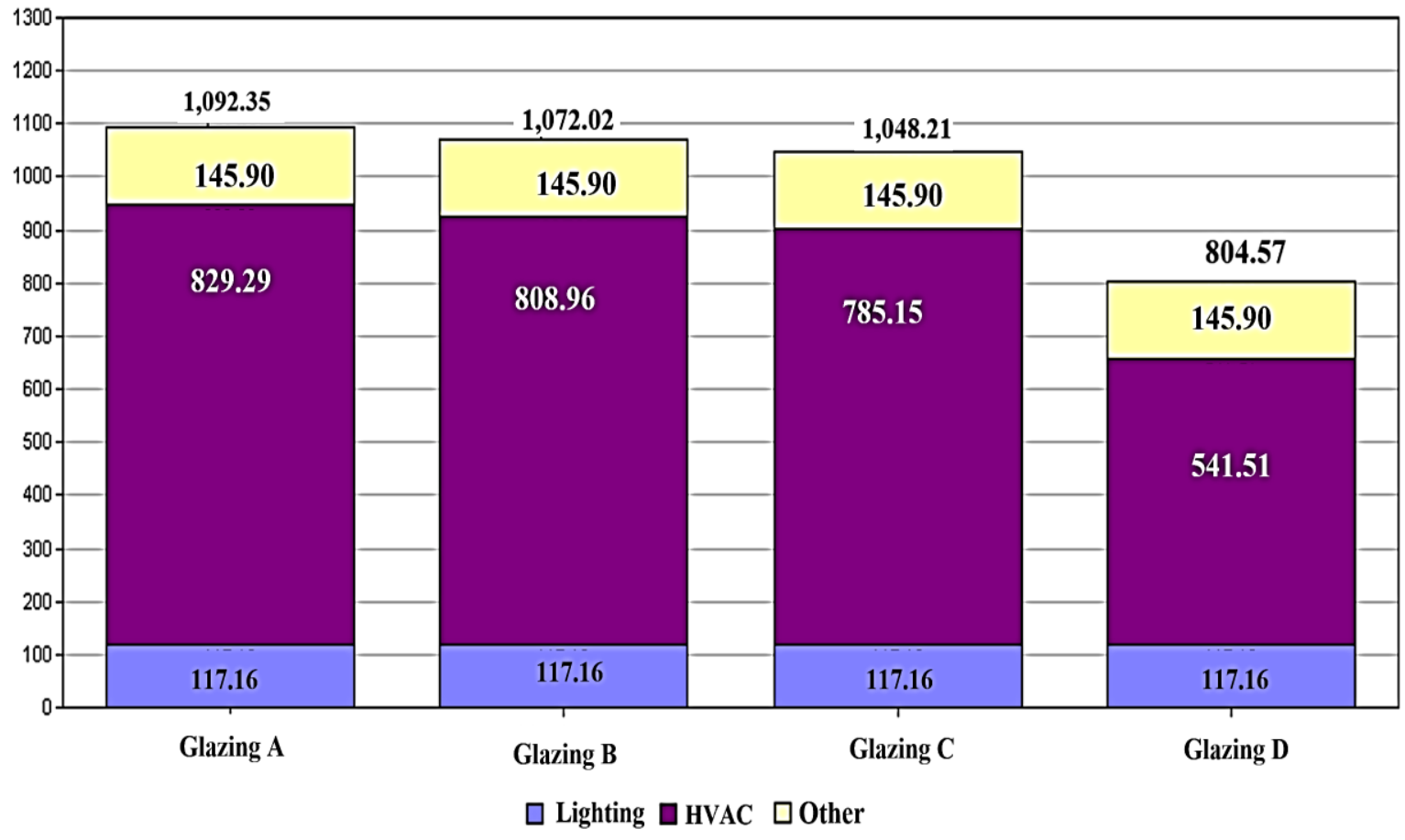

Figure 11. Electricity performance summary for use per conditioned floor area.

Considering the energy requirement for HVAC in $4 \mathrm{~mm}$ thick Glazing A and Glazing B; Glazing B with emission feature requires less energy in the same square meter. The same applies to Glazing $\mathrm{C}$ and Glazing D of $6 \mathrm{~mm}$ thickness. It is observed that Glazing D with emission feature, especially among the Glazing with $6 \mathrm{~mm}$ thickness, provides energy saving at a significant amount of energy. For the four types of glass, Glazing D can be accepted as the most optimal in terms of electricity consumption and annual HVAC.

The building heating and cooling electricity peak demand performance according to the months is shown in Figs. 12 and 13.

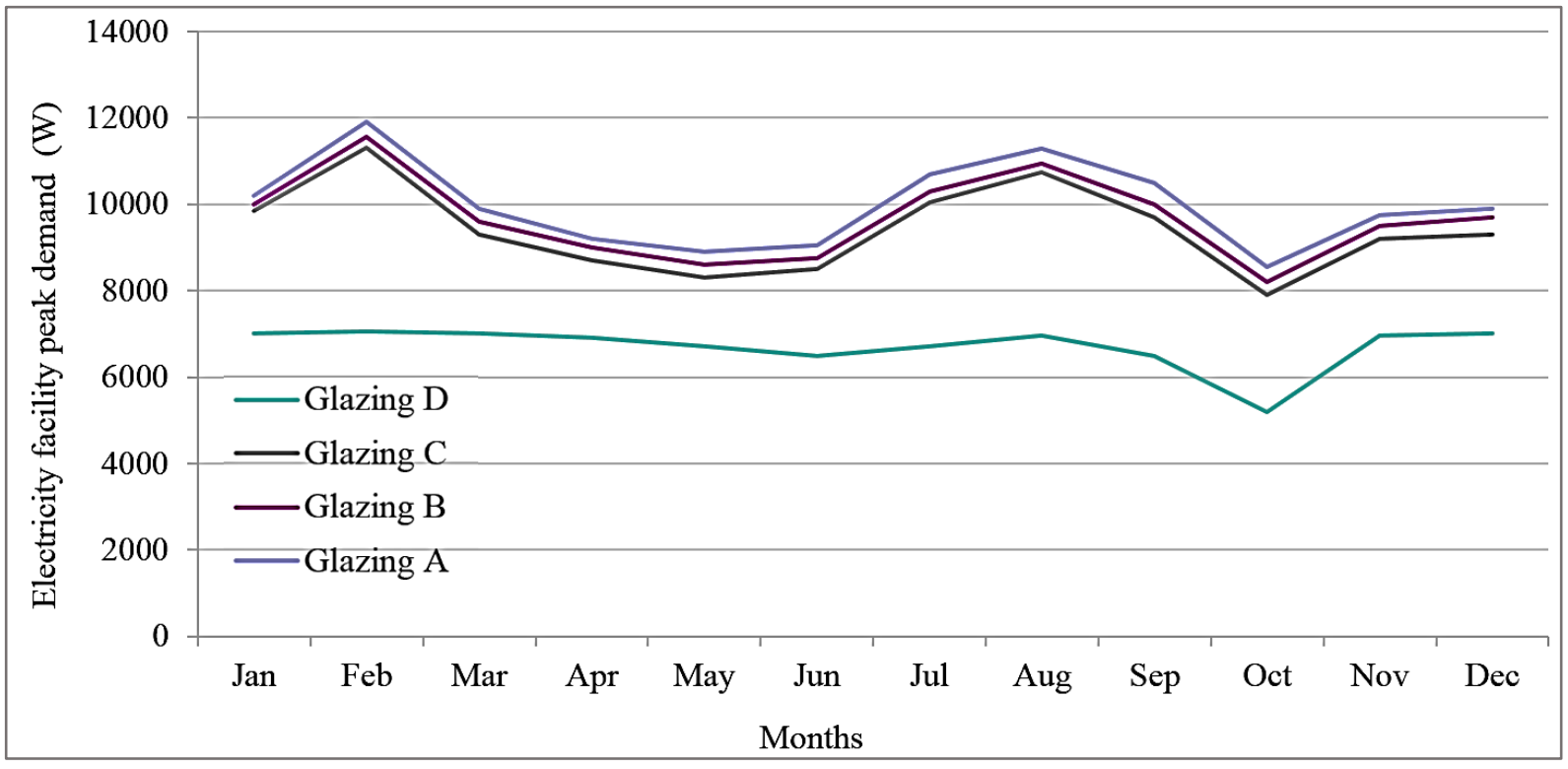

Figure 12. Electricity facility peak demand (W) 
Milorad Boji was found that the application of low-E glazing would lead to a decrease in cooling electricity use by up to $4.2 \%$ [39].

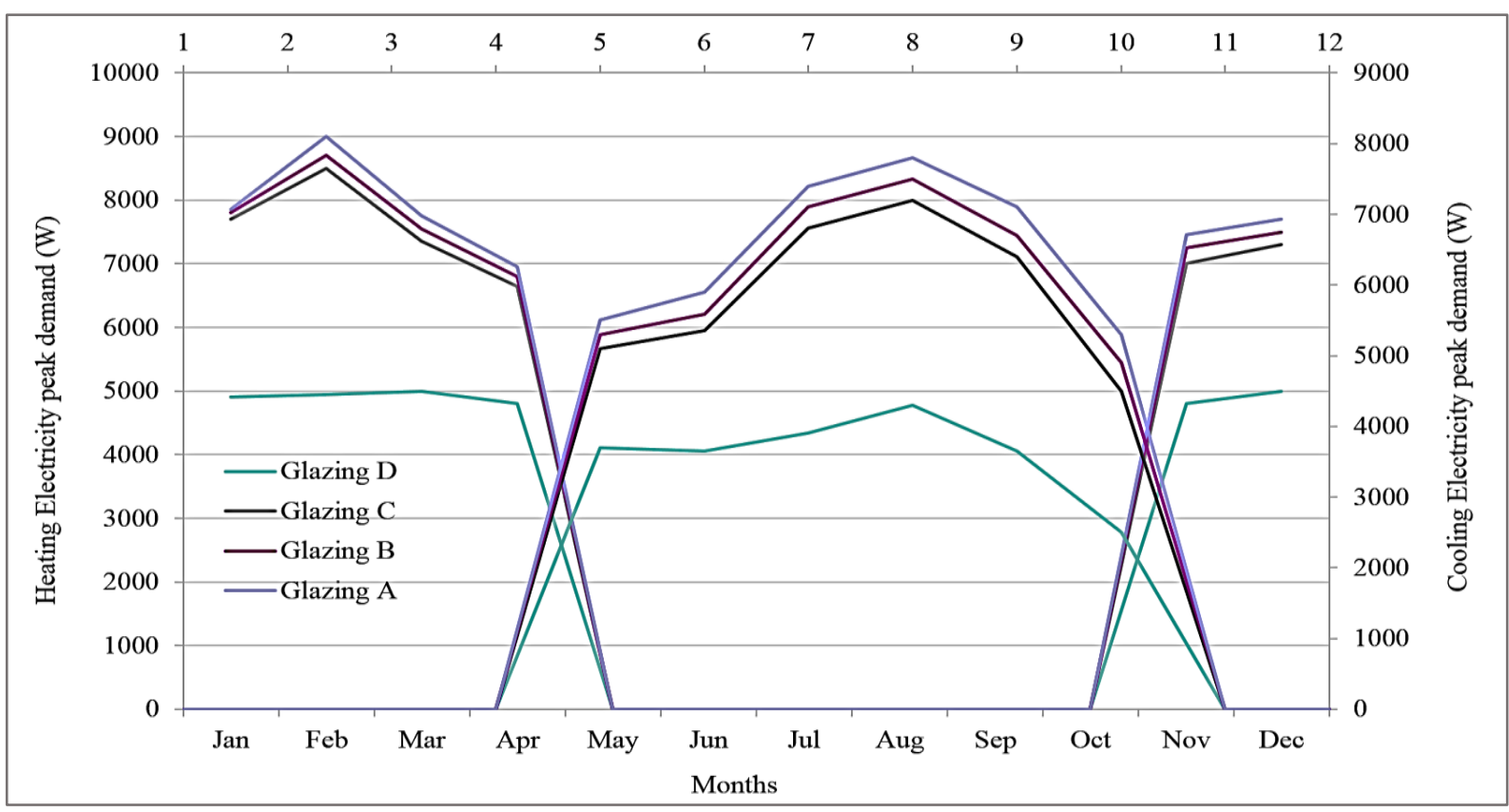

Figure 13. Heating and cooling electricity peak demand (W).

Figs. 12, 13 gives the monthly load profiles for the HVAC system in the modeled office building for the complete year.

The results show that the total cooling peak demand load was around 6500-8000 W for Glazing A, B, and D. As shown in Fig. 10, the minimum cooling load value in August was around $4000 \mathrm{~W}$ for all Glazing D. The graph becomes a parabola with its maximum at the ends and the minimum in the middle in winter, however, the cooling power is decreased. By contrast, the highest heating power points are in January and February, specifically in February with a value of $9000 \mathrm{~W}$ for Glazing A, B, and D. Glazing $\mathrm{D}$ was not visible in a sudden increase and growth.

There is peak cooling load demand in August, and peak heating load demand in January and February. Glazing A, Glazing C (clear glass glazing), and Glazing B (In Low emissivity Glazing with $4 \mathrm{~mm}$ thickness) have more cooling and heating load according to the Glazing D (In Low emissivity Glazing). In Glazing D, which is Low emissivity glazing, it is observed from the simulation results that the cooling energy decreases with the low-emissivity glass because of the higher overall reflectance of solar energy. The heating energy requirements also decrease due to the low heat transfer coefficient. It is possible to provide a considerable decrease in the sensible heat gains and the depending cooling loads by changing the glazing types. This decrease is due to the decline of the heat gain from solar radiation and conduction [40].

Milorad Boji found that the application of low-E glass will result in a reduction in cooling electricity use [39]. In Fig. 13, it also was observed that glazing D reduced cooling and heating energy by up to approximately $30 \%$ compared to Glazing.

\section{CONCLUSIONS}


This article is focused on optimizing the effective energy consumption of office buildings and a computational design model has been prepared for this article where different types of glass can be defined using energy software programs.

The main purpose of this paper is to achieve optimum Glazing material type which guides us to have an office building with optimum energy consumption.

The following is a comparison of the results of the office building conditions and the results of the four architectural improvements relating to Glazing A, Glazing B, Glazing C, and Glazing D types. Once the office model was analyzed the simulation results were created to compare the difference between the various cases. As shown in study results, the office is heating dominated during November-April months, the cooling energy use was significant during April-October months. Peak points of heating were observed in February for four glazing combinations. In cases where emission glass was used in February, the need for a fan decreased compared to other situations. The least need was observed in Glazing D. If the glazing cases are compared in terms of heating load, Glazing D has less heating and cooling load demand than Glazing A, B, and C, especially due to its emission and thickness properties.

Nowadays, energy modeling can be done and the loads, consumption, and energy behavior of buildings can be calculated and the energy use density of buildings can be calculated by combining all the resulting results. Energy Use Intensity (EUI) is defined as energy consumption per unit area, especially in the field of building technologies, and is used in energy measurement. By looking at this value, the energy efficiency of the building can be evaluated. Considering the energy consumption density in our models, it was found to be $95.73 \mathrm{kBtu} / \mathrm{ft} 2,94.40 \mathrm{kBtu} / \mathrm{ft} 2,92.30 \mathrm{kBtu} / \mathrm{ft} 270.85 \mathrm{kBtu} / \mathrm{ft} 2$ for Glazing A, Glazing B, Glazing C, and Glazing D, respectively. These values are considerably higher than the literature articles and Miliopoulos R. [41] undergraduate thesis, "Use of Energy in Office Buildings".

While designing buildings, attention should be paid to energy efficiency, in this process architects and engineers have a great job. Incorrectly designed structures can be strengthened later. In other words, the energy efficiency of buildings can be increased by many methods such as thermal insulation of buildings, strengthening them with materials with low thermal conductivity, using more efficient doors and frames in terms of energy consumption, and adopting some renewable energy systems. However, this is a negative situation when the unnecessary use of resources and financial aspects are considered.

In the literature, it has been determined that the amount of savings obtained from window systems will vary depending on the direction of the building wings, the type, and location of the rooms. For this reason, it will be studied as a continuation of this subject in future studies.

\section{REFERENCES}

[1] Rezvani, F. Energy modelling and u-value calculation of Scottish house elements: assessment of thermal performance improvement. PhD, Universidad de Zaragoza, Zaragoza, Spain, 2019.

[2] Borbon-Almada, A, Rodriguez-Muñoz, N, Najera-Trejo, M. Energy and Economic Impact on the Application of Low-Cost Lightweight Materials in Economic Housing Located in Dry Climates. Sustainability 2019; 11(6): 1586.

[3] Yazdi, MB, Sabzevar, HB. Comparing the Thermal Efficiency of Courtyard and Atrium. International Journal of Engineering and Technology 2020;12(2):95-100.

[4] Le-Trung, K, Lee, K, Lee, J, Lee, DH. Evaluation of seismic behavior of steel special moment frame buildings with vertical irregularities. The Structural Design of Tall and Special Building 2012; Mar;21(3):215-32.

[5] Alghoul, SAHG. The impact of external window shading on energy requirements of office buildings. Journal of Multidisciplinary Engineering Science and Technology (JMEST). 2016; 3:2458-9403.

[6] Atzeri, A, Cappelletti, F, Gasparella A. Internal Versus External Shading Devices Performance in Office Buildings. Energy Procedia 2014; 45:463-72.

[7] Littlefair, P. Design for Improved Solar Shading Control. In London, ENGLAND: CIBSE; 2006. 
[8] ASHRAE handbook: Fundamentals. American Society of Heating Refrigerating Air-Conditioning Engineers. Atlanta: GA: ASHRAE; 1997.

[9] Wang, D, Lu, L, Zhang W. Overall Energy Performance Assessment of a New Heat Blocking Coating. Journal of Sustainable Development of Energy, Water and Environment Systems 2019;7(1):1-12.

[10] Zhang, XPD. Patent No. 8,859,09. Washington, D. C., USA; 2014.

[11] Chiba, K, Takahashi, T, Kageyama, T, Oda, H. Low-emissivity coating of amorphous diamond-like carbon/Ag-alloy multilayer on glass. Applied Surface Science 2005; 246(1-3):48-51.

[12] Chen, X, Yang, H, Zhang, W. A comprehensive sensitivity study of major passive design parameters for the public rental housing development in Hong Kong. Energy 2015; 93:1804-18.

[13] Zhang, W, Lu, L, Peng, J, Song, A. Comparison of the overall energy performance of semi-transparent photovoltaic windows and common energy-efficient windows in Hong Kong. Energy and Buildings 2016; 128:511-8.

[14] Tahouri, A. Evaluation of Windows and Energy Performance Case-Study: Colored Building. PhD, Eastern Mediterranean University (EMU), Gazimağusa, North Cyprus, 2015.

[15] Arasteh, DAJHY. Future advanced windows for zero-energy homes. ASHRAE Transactions. 2003; 109:87182.

[16] Gueymard, CA, duPont WC. Spectral effects on the transmittance, solar heat gain, and performance rating of glazing systems. Solar Energy 2009; 83(6):940-53.

[17] Mateus, NM, Pinto, A, Graça GC da. Validation of EnergyPlus thermal simulation of a double skin naturally and mechanically ventilated test cell. Energy and Buildings. 2014; 75:511-22.

[18] Fumo, N, Mago, P, Luck, R. Methodology to estimate building energy consumption using EnergyPlus Benchmark Models. Energy and Buildings. 2010; Dec; 42(12):2331-7.

[19] Fuertes, JOM, MMMJMAA. Modelación Térmica De Un Módulo Experimental De Vivienda Alto Andina Utilizando Openstudio Y Energyplus [Thermal Modeling of a High Andean Housing Experimental Module Using Openstudio and Energyplus]. In: XXIV Peruvian Symposium on Solar Energy and the Environment. Huaraz; 2017.

[20] Saafi, K, Daouas, N. Energy and cost efficiency of phase change materials integrated in building envelopes under Tunisia Mediterranean climate. Energy 2019; 187:115987.

[21] University of Illinois and Ernest Orlando Lawrence Berkeley national laboratory. EnergyPlus engineering reference, Version 9.1.0 documentation. 2019.

[22] Daouas, N. Impact of external longwave radiation on optimum insulation thickness in Tunisian building roofs based on a dynamic analytical model. Applied Energy 2016; 177:136-48.

[23] Alghoul, SK, Rijabo, HG, Mashena, ME. Energy consumption in buildings: A correlation for the influence of window to wall ratio and window orientation in Tripoli, Libya. Journal of Building Engineering 2017; 11:82-6.

[24] Gasparella, A, Pernigotto, G, Cappelletti, F, Romagnoni, P, Baggio, P. Analysis and modelling of window and glazing systems energy performance for a well-insulated residential building. Energy and Buildings 2011; 43(4): 1030-7.

[25] Sadrzadehrafiei, S SKLC. Application of advanced glazing to mid-rise office buildings in Malaysia. In: Niola $\mathrm{V}, \mathrm{Ng} \mathrm{KL}$, editors. proceedings of the $9^{\text {th }}$ WSEAS international conference on environment. Montreau: Ecosystems and development (EED'11); 2011. p. 197-201.

[26] Ebrahimpour, A, Maerefat, M. Application of advanced glazing and overhangs in residential buildings. Energy Conversion and Management 2011;52(1):212-9.

[27] Susorova, I, Tabibzadeh, M, Rahman, A, Clack, HL, Elnimeiri, M. The effect of geometry factors on fenestration energy performance and energy savings in office buildings. Energy and Buildings 2013; 57:6-13.

[28] Jelle, BP, Hynd, A, Gustavsen, A, Arasteh, D, Goudey H, Hart R. Fenestration of today and tomorrow: A state-of-the-art review and future research opportunities. Solar Energy Materials and Solar Cells 2012; 96:128.

[29] Amaral, AR, Rodrigues, E, Gaspar, AR, Gomes, Á. A thermal performance parametric study of window type, orientation, size, and shadowing effect. Sustainable Cities and Society 2016; Oct; 26:456-65.

[30] Djamel, Z, Noureddine, Z. The Impact of Window Configuration on the Overall Building Energy Consumption under Specific Climate Conditions. Energy Procedia 2017; 115:162-72.

[31] Aram, R, Alibaba, H. Thermal Comfort and Energy Performance of Atrium in Mediterranean Climate. Sustainability 2019; 25;11(4):1213.

[32] Pilechiha, P BBNM. Energy Optimization of Double-Glazed Window Parameters in Hot and Arid Climate (Case Study: The Southern Front of an Office Building in Tehran). Hoviatshahr. 2021; 15(3):5-14.

[33] Dutta, A, Samanta A, Neogi, S. Influence of orientation and the impact of external window shading on building thermal performance in tropical climate. Energy and Buildings 2017; 139:680-9.

[34] Barrios G, Huelsz G, Rojas J. Ener-Habitat: A Cloud Computing Numerical Tool to Evaluate the Thermal Performance of Walls/Roofs. Energy Procedia 2014; 57:2042-51. 
[35] Lee, EDDSSE. Thermal and daylighting performance of an automated venetian blind and lighting system in a full-scale private office. Energy and Buildings 1998; 29:47-63.

[36] Nielsen, MV, Svendsen S, Jensen, LB. Quantifying the potential of automated dynamic solar shading in office buildings through integrated simulations of energy and daylight. Solar Energy 2011; 85(5):757-68.

[37] Usta, P, Zengin, B. The Energy Impact of Building Materials in Residential Buildings in Turkey. Materials $2021 ; 14(11): 2793$

[38] International Energy Agency. WEO-2015 Special Report: Energy and Climate Change. IEA: Paris, France; 2015.

[39] Bojić, M. Application of overhangs and side fins to high-rise residential buildings in Hong Kong. Civil Engineering and Environmental Systems 2006; 23(4):271-85.

[40] Eskin, N, Türkmen, H. Analysis of annual heating and cooling energy requirements for office buildings in different climates in Turkey. Energy and Buildings 2008; 40(5):763-73.

[41] Miliopoulos, R. Building Energy Modeling using EnergyPlus and OpenStudio Building. Msc, University of Thessal, Volos, Greek, 2017. 